\title{
IMPLEMENTASI GLS (GERAKAN LITERASI SEKOLAH) MELALUI PENGADAAN PERPUSTAKAAN MINI DI SDN-6 MADUREJO TAHUN 2018
}

\section{Implementation Of GLS (School Literation Movement) Through The Procurement Of Mini Library In SDN-6 Madurejo In 2018}

\section{Sriwati}

*email: sriwati@gmail.com

\section{Kata Kunci:}

Literasi Sekolah

budi pekerti

kearifan lokal

\section{Keywords:}

School Literacy

character

local culture

\section{Accepted}

September 2019

Published

Desember 2019

\begin{abstract}
Abstrak
Gerakan Literasi Sekolah adalah sebuah gerakan dalam upaya menumbuhkan budi pekerti siswa yang bertujuan agar siswa memiliki budaya membaca dan menulis sehingga tercipta pembelajaran sepanjang hayat. Kegiatan rutin ini dilaksanakan untuk menumbuhkan minat baca peserta didik serta meningkatkan keterampilan membaca. Materi baca berisi nilai-nilai budi pekerti, berupa kearifan lokal, nasional, dan global yang disampaikan sesuai tahap perkembangan peserta didik.

Minat baca merupakan salah satu kunci sukses seseorang dalam mengetahui dan menambah wawasan pengetahuannya. Kegiatan-kegiatan untuk meningkatkan minat baca harus diadakan dan digalakan. Sejalan dengan perkembangan ilmu pengetahuan dan teknologi yang semakin pesat, terutama dalam teknologi percetakan maka semakin banyak informasi yang tersimpan di dalam buku. Pada semua jenjang pendidikan, kemampuan membaca menjadi skala prioritas yang harus dikuasai siswa. Dengan membaca siswa akan memperoleh berbagai informasi yang sebelumnya belum pernah didapatkan.
\end{abstract}

\footnotetext{
Abstract

The School Literacy Movement is a movement in an effort to foster student character that strives for students to have a culture of reading and writing so as to create lifelong learning. This routine activity is carried out to foster students' interest in reading and improve reading skills. The reading material contains the values of character, consisting of local, national and global wisdom, which are delivered according to the participants' development

Interest in reading is one of the keys to one's success in knowing and adding insights to his knowledge. Activities to increase reading interest must be held and promoted. In line with the rapid development of science and technology, the more in printing technology the more information stored in books. At all levels of education, reading ability becomes a priority scale that students must master. By reading students will obtain various information that has never been obtained before.
} 


\section{PENDAHULUAN}

Gerakan Literasi Sekolah adalah sebuah gerakan dalam upaya menumbuhkan budi pekerti siswa yang bertujuan agar siswa memiliki budaya membaca dan menulis sehingga tercipta pembelajaran sepanjang hayat. Kegiatan rutin ini dilaksanakan untuk menumbuhkan minat baca peserta didik serta meningkatkan keterampilan membaca. Materi baca berisi nilai-nilai budi pekerti, berupa kearifan lokal, nasional, dan global yang disampaikan sesuai tahap perkembangan peserta didik.

Minat baca merupakan salah satu kunci sukses seseorang dalam mengetahui dan menambah wawasan pengetahuannya. Kegiatan-kegiatan untuk meningkatkan minat baca harus diadakan dan digalakan. Sejalan dengan perkembangan ilmu pengetahuan dan teknologi yang semakin pesat, terutama dalam teknologi percetakan maka semakin banyak informasi yang tersimpan di dalam buku. Pada semua jenjang pendidikan, kemampuan membaca menjadi skala prioritas yang harus dikuasai siswa. Dengan membaca siswa akan memperoleh berbagai informasi yang sebelumnya belum pernah didapatkan.

Minat baca siswa dapat di tingkatkan melalui gerakan literasi sekolah. Literasi Sekolah dalam konteks GLS pada panduan gerakan Literasi Sekolah di SD adalah kemampuan mengakses, memahami, dan menggunakan sesuatu secara cerdas melalui berbagai aktivitas, antara lain membaca, melihat, menyimak, menulis, dan/atau berbicara.

Literasi sebaiknya, bukanlah sebagai hal yang musiman. Banyak kegiatan yang dilaksanakan berdasarkan proyek, dalam artian kegiatan terlaksana dengan baik selama proyek itu berlangsung, tapi pada saat proyek dan dana terhenti, kegiatanpun akan terhenti pula. Untuk meningkatkan gerakan literasi sekolah perlu perpustakaan yang menarik bagi siswa, yaitu menyediakan perpustakaan mini. Perpustakaan mini berarti perpustakaan yang menyediakan buku dalam jumlah yang sangat terbatas.
Dari latar belakang itulah maka penelitian ini mengambil judul: "Implementasi GLS (Gerakan Literasi Sekolah) Melalui Pengadaan Perpustakaan Mini di SDN-6 Madurejo Tahun 2018”

\section{TINJAUAN PUSTAKA}

\section{A. GLS (Gerakan Literasi Sekolah)}

I. Faktor-faktor mempengaruhi proses belajar

yang

Dalam kegiatan belajar mengajar atau proses pembelajaran terdapat faktor-faktor yang dapat mempengaruhi proses belajar siswa. Secara umum faktor-faktor tersebut dapat dibedakan menjadi dua kategori yaitu, faktor internal dan faktor eksternal.

\section{Faktor Internal Pembelajaran Mempengaruhi GLS}

Minat baca siswa perlu ditumbuhkan agar mereka mencintai pengetahuan. Kemampuan membaca siswa perlu ditingkatkan bukan hanya untuk meningkatkan keterampilan memahami bacaan siswa Indonesia yang terpuruk pada peringkat 64 dari 65 negara yang berpartisipasi dalam tes Programme of International Student Assessment (PISA); tapi juga untuk menjadikan siswa sebagai pembelajar sepanjang hayat.

\section{Sekolah)}

3. Tahapan GSL (Gerakan Literasi

Ada beberapa tahapan yang bisa dilaksanakan oleh sekolah yang bisa dijadikan sebagai acuan dalam proses peningkatan gerakan literasi sekolah berupa tahapan pembiasaan, pengembangan dan pembelajaran. Tahapan ini efektif untuk peningkatan GLS, apalagi jika dilaksanakan secara berkesinambungan dan istiqomah oleh seluruh pelaku pembelajar, peserta didik, guru dan sudah tentu Kepala Sekolah sebagai pimpinan dan pemangku kebijakan.

\section{Faktor Pendukung GSL}

Keberhasilan Literasi di tak lepas dari beberapa pihak dan Wadah diantarannya:

$$
>\text { Man Power }
$$

$>$ Kepala Sekolah

Kepala Sekolah sebagai pemimpin tertinggi di lingkungan Sekolah merupakan 
sosok yang sangat berperan dalam kemajuan Literasi di sekolah.

\section{B. Pola Perpustakaan Mini}

\section{Pengertian Perpustakaan Mini}

Perpustakaan mini berarti perpustakaan yang menyediakan buku dalam jumlah yang sangat terbatas.

Darmono mengemukakan bahwa Perpustakaan pada hakekatnya adalah pusat sumber belajar dan sumber informasi bagi pemakainya. Perpustakaan dapat pula diartikan sebagai tempat kumpulan buku-buku atau tempat buku-buku dihimpun dan diorganisasikan sebagai media belajar siswa.

Pengertian perpustakaan adalah kumpulan bahan informasi yang terdiri dari bahan buku/book materials dan bahan nonbuku/nonbook materials yang disusun dengan sistem tertentu dipersiapkan untuk diambil manfaatnya/pengertiannya, tidak untuk dimiliki sebagian maupun keseluruhan. Ibnu Ahmad Saleh memberikan definisi perpustakaan adalah tempat pengumpulan pustaka atau kumpulan pustaka yang diatur dan disusun dengan sistem tertentu, sehingga sewaktu-waktu diperlukan dapat ditemukan dengan mudah dan cepat.

\section{Tujuan Perpustakaan}

Tujuan perpustakaan tidak dapat lepas dari fungsi perpustakaan. Diantara tujuan pokok didirikannya sebuah perpustakaan adalah :

a) Menyediakan sarana atau tempat untuk menghimpun berbagai sumber informasi untuk dikoleksi secara terus menerus, diolah dan diproses.

b) Sebagai sarana atau wahana untuk melestarikan hasil budaya manusia (ilmu pengetahuan, teknologi dan budaya) melalui aktifitas pemeliharaan dan pengawetan koleksi.

c) Sebagai agen perubahan (Agent of changes) dan agen kebudayaan serta pusat informasi dan sumber belajar mengenai masa lalu, sekarang, dan masa akan datang. Selain itu, juga dapat menjadi pusat penelitian, rekreasi dan aktifitas ilmiah lainnya.

d) Menciptakan budaya membaca untuk mencerahkan masa depan bangsa. Karena dari membaca inilah kita dapat memperoleh berbagai macam pengetahuan yang berguna untuk menjadi bekal di kehidupan kita yang akan datang.

\section{Fungsi Perpustakaan}

Perpustakaan mempunyai beberapa fungsi, yang diantaranya adalah:
a) Fungsi penelitian
b) Fungsi pendidikan
c) Fungsi rekreasi
d) Fungsi informasi

4. Jenis-jenis Perpustakaan

a) Perpustakaan Negara

Kebanyakan negara di dunia mempunyai perpustakaan negaranya sendiri. Perpustakaan negara memainkan peranan penting dalam membangun dan menyelaras berbagai isu berkaitan perpustakaan dan profesion pustakawan.

b) Perpustakaan awam

Perpustakaan awam termasuk perpustakaan negeri, perpustakaan daerah, dan perpustakaan desa.

c) Perpustakaan akademik

Perpustakaan akademik adalah perpustakaan di institusi pengajian tinggi seperti university, kolej dan maktab.

d) Perpustakaan sekolah

Setiap sekolah biasanya dilengkapi dengan perpustakaan atau dipanggil pusat sember. Saiz perpustakaan sekolah kebanyakan adalah kecil dengan koleksi bahan yang sederhana.

e) Perpustakaan khusus

Perpustakaan khusus adalah perpustakan yang berada di dalam sebuah organisasi ataupun syarikat.

\section{METODE PENELITIAN}

\section{A. Kondisi Subyek Penelitian}

Penelitian ini dilaksanakan di SDN-6 Madurejo dengan subjek penelitian adalah guru kelas dan guru mata pelajaran yang ada di sekolah dasar ini, baik yang sudah pegawai negeri sipil maupun yang masih wiyata bakti. Jumlah seluruh dewan guru yang menjadi subyek penelitian adalah adalah 9 orang.

Kondisi di sekolah binaan belum ada GSL (Gerakan Literasi Sekolah), makanya peneliti hendak mengimplementasikan GSL 
(Gerakan Literasi Sekolah) di sekolah binaan peneliti.

\section{B. Waktu Penelitian}

Pengambialan data dilakukan pada tanggal Februari 2018 sampai dengan April 2018, dengan perincian kegiatan sebagai berikut:

\begin{tabular}{|c|c|c|}
\hline $\mathrm{NO}$ & Kegiatan & Tanggal / Bulan \\
\hline $\mathrm{I}$ & $\begin{array}{l}\text { Kegiatan } \\
: \\
\text { a. Pengamatan } \\
\text { awal } \\
\text { b. Merumuskan } \\
\quad \text { judul } \\
\text { c. Penyusunan } \\
\text { Instrumen }\end{array}$ & $\begin{array}{c}8-28 \text { Februari } \\
2018\end{array}$ \\
\hline \multirow[t]{3}{*}{2} & $\begin{array}{l}\text { Pengumpulan } \\
\text { data } \\
\text { melaksanakan } \\
\text { tindakan } \\
\text { a. Pengumpulan } \\
\quad \text { Data }\end{array}$ & $\begin{array}{l}\text { I-I5 Maret } \\
2018\end{array}$ \\
\hline & $\begin{array}{l}\text { b. Pelaksanaan } \\
\text { Siklus I dan } \\
\text { analisis hasil } \\
\text { siklus I }\end{array}$ & $\begin{array}{c}\text { I7-30 Maret } \\
2018\end{array}$ \\
\hline & $\begin{array}{l}\text { C. Pelaksanaan } \\
\text { Siklus } 2 \text { dan } \\
\text { analisis hasil } \\
\text { siklus } 2\end{array}$ & I-I5 April 2018 \\
\hline 3 & $\begin{array}{l}\text { Penyusunan } \\
\text { Laporan } \\
\text { Penelitian }\end{array}$ & $\begin{array}{c}16 \text { april - } 5 \\
\text { Mei } \\
2018\end{array}$ \\
\hline
\end{tabular}

\section{Prosedur Penelitian}

\section{Siklus I}

\section{a. Perencanaan}

Pada tahap ini peneliti merumuskan dan mempersiapkan: rencana jadwal pelaksanaan tindakan, rencana pelaksanaan pembinaan kedisiplinan, membuat lembar observasi, dan mempersiapkan kelengkapan lain yang diperlukan dalam rangka analisis data.

b. Tahap Pelaksanaan

Pelaksanaan pembinaan kedisiplinan

Siklus I dilaksanakan selama I X pertemuan dalam seminggu. Pelaksanaan tindakan pada dasarnya disesuaikan dengan setting tindakan yang telah ditetapkan dalam rencana pelaksanaan.

\section{c. Pengamatan}

Setelah proses bembinaan GSL (Gerakan Literasi Sekolah) selesai maka dilakukan pengamatan selama seminggu terhadap sekolah. Pengamatan dilakukan untuk mengetahui implementasi GSL (Gerakan Literasi Sekolah)

\section{d. Refleksi}

Refleksi merupakan kegiatan menganalisis semua data atau informasi yang dikumpulkan dari penelitian tindakan yang dilaksanakan, sehingga dapat diketahui berhasil atau tidaknya tindakan yang telah dilaksanakan dengan tujuan yang diharapkan.

\section{Siklus 2}

\section{a. Perencanaan}

Pada tahap ini peneliti merumuskan dan mempersiapkan melakukan tindak lanjut siklus I, yaitu dalam siklus II dilakukan perbaikan. Peneliti yang dalam hal ini adalah pengawas Sekolah mencari kekurangan dan kelebihan mengetahui implementasi GSL (Gerakan Literasi Sekolah) Melalui pola perpustakaan mini. Kelebihan yang ada pada siklus I dipertahankan pada siklus II, sedangkan kekurangannya diperbaiki. Peneliti menyiapkan lembar evaluasi (penilaian), lembar observasi untuk mengetahui implementasi GSL (Gerakan Literasi Sekolah) Melalui pola perpustakaan mini.

\section{b. Tahap Pelaksanaan}

Pelaksanaan Siklus II juga dilaksanakan I kali selama seminggu. Proses tindakan pada siklus II dengan melaksanakan program bembinaan kediplinan berdasarkan pada pengalaman hasil dari siklus I. Dalam tahap ini peneliti melaksanakan metode yang diterapkan berdasarkan Tindakan pada siklus I, perbedaannya adalah pada siklus II dilaksanakan dengan pengontrolan implementasi GSL (Gerakan Literasi Sekolah) Melalui pola perpustakaan mini.

\section{c. Pengamatan}

Setelah proses bembinaan kedisiplinan selesai maka dilakukan pengamatan selama 
seminggu terhadap implementasi GSL

(Gerakan Literasi Sekolah). Pengamatan dilakukan untuk mengetahui implementasi GSL (Gerakan Literasi Sekolah) Melalui pola perpustakaan mini. Adapun yang di amati pada siklus 2 sama dengan yang diamati pada siklus I.

\section{d. Refleksi}

Refleksi merupakan kegiatan menganalisis semua data atau informasi yang dikumpulkan dari penelitian tindakan yang dilaksanakan, sehingga dapat diketahui berhasil atau tidaknya tindakan yang telah dilaksanakan dengan tujuan yang diharapkan.

\section{Metode Pengumpulan Data}

Agar pelaksanaan pembinaan kedisiplinan yang dilakukan dapat berjalan dengan baik, peneliti mengadakan pengamatan langsung terhadap GSL (Gerakan Literasi Sekolah) Melalui pola perpustakaan mini.

Teknik pengumpulan data memiliki peranan penting, hal tersebut disebabkan karena pemerolehan data dalam sebuah penelitian akan dijadikan sebagai bahan dan bukti untuk dijadikan sebagai pegangan dalam melakukan penilaian. Suharsimi Arikunto (2006: I50-I58) menyebutkan bahwa "Jenis metode pengumpulan data terdiri dari tes, angket atau kuesioner, interview, observasi, skala bertingkat, dan dokumentasi”.

\section{E. Indikator Kinerja}

Tujuan penelitian tindakan sekolah yang di lakukan pada di SDN-6 Madurejo adalah untuk mengimplementasikan GSL (Gerakan Literasi Sekolah) Melalui pola perpustakaan mini. GSL (Gerakan Literasi Sekolah) Melalui pola perpustakaan mini dapat di laksanakan dengan baik, maka indikator kinerja berikutnya apabila hasil penelitian ini dengan valid dapat menunjukkan:

a. Ada perpustakaan mini di setiap kelas

b. Terdapat buku-buku anak di dalam perpustakaan mini.

\section{HASIL PENELITIAN PEMBAHASAN}

\section{A. Hasil Penelitian}

I. Persiapan Sebelum Penelitian

Peneliti mengadakan beberapa persiapan yang diperlukan sebelum pelaksanaan penelitian. Adapun persiapan yang peneliti lakukan sebelum penelitian adalah sebagai berikut:

a. Melakukan observasi awal untuk mengidentifikasi masalah melalui wawancara dengan guru di SDN-6 Madurejo

b. Peneliti meminta persetujuan izin riset

c. Melakukan observasi lanjutan untuk mencari informasi tentang GSL (Gerakan Literasi Sekolah).

\section{Siklus I}

Implementasi gerakan literasi yang ada di SDN-6 Madurejo yaitu mengacu penuh pada buku pedoman yang diterbitkan oleh kementerian pendidikan dan kebudayaan (kemendikbud). Buku yang berjudul gerakan literasi sekolah yang ada disekolah tersebut didapat melalui fasilitas internet dengan cara mendownload sendiri, sebab kemendikbud tidak mendistribusikan buku panduan literasi yang diterbitkanya secara langsung kesekolahsekolah.

Adapun dalam pelaksanaan kegiatan gerakan literasi SDN-6 Madurejo, sekolah ini memiliki srtuktur penanggung jawab yang diketuai oleh kepala yang bertugas megawasi serta mejadikan motor atau penggerak utama jalanya kegiatan literasi SDN-6 Madurejo. Perpustakaan mini di sekolah menjadi media pendukung utama sebab di dalam perpustakaan terdapat berbagai sumber ilmu serta informasi yang bisa dengan mudah didapat oleh warga sekolah yaitu dengan membaca koleksi buku-buku yang ada. Berikut adalah tahapan proses impelentasi gerakan literasi yang ada di sekolah SDN-6 Madurejo:

a. Persiapan gerakan literasi sekolah

b. Pelaksanaan Gerakan Literasi Sekolah

c. Observasi

Observasi yang di lakukan peneliti adalah dengan menceklist lembar observasi yang telah di buat. Lembar observasinya adalah sebagai berikut:

Tabel 4.I Observasi Gerakan Literasi Sekolah 


\begin{tabular}{|l|l|l|}
\hline ASPEK YA & TIDAK \\
\hline $\begin{array}{l}\text { Ada perpustakaan mini di } \\
\text { setiap kelas }\end{array}$ & & \\
\hline $\begin{array}{l}\text { Terdapat buku-buku dalam } \\
\text { perpustakaan mini di setiap } \\
\text { kelas }\end{array}$ & & \\
\hline $\begin{array}{l}\text { Siswa melaksanakan gerakan } \\
\text { literasi sebelum memulai } \\
\text { pelajaran }\end{array}$ & \\
\hline $\begin{array}{l}\text { Guru membimbing siswa } \\
\text { melaksanakan gerakan } \\
\text { literasi buku- }\end{array}$ & \\
\hline $\begin{array}{l}\text { Sekolah menfasilitasi buh } \\
\text { buku untuk di jadikan koleksi } \\
\text { di perpustakaan mini }\end{array}$ & \\
\hline
\end{tabular}

Hasil dari observasi siklus I adalah Ada perpustakaan mini di setiap kelas, Terdapat buku-buku dalam perpustakaan mini di setiap kelas, Siswa melaksanakan gerakan literasi sebelum memulai pelajaran, Guru membimbing siswa melaksanakan gerakan literasi, Sekolah menfasilitasi buku-buku untuk di jadikan koleksi di perpustakaan mini. Artinya Gerakan Literasi Sekolah melalui perpustakaan mini di SDN-6 Madurejo sudah bagus.

d. Refleksi

Keberhasilan dalam proses kegiatan literasi sekolah yang ada di SDN-6 Madurejo tidak lepas dari beberapa faktor pendukung ataupun kendala yang mempengaruhinya.

\section{Siklus II}

Implementasi gerakan literasi yang ada di SDN-6 Madurejo, seperti yang peneliti amati dari mengikuti kegiatan literasi secara langsung ataupun menganalisa hasil wawancara dari berbagai pihak, maka gerakan literasi yang ada di sekolah ini sudah sampai kepada tahap pembelajaran. Mengingat pada prinsipnya kegiatan literasi pada tahap pembiasaan sama dengan tahap pengembangan. Yang membedakan adalah bahwa kegiatan 15 menit membaca baik didalam hati ataupun secara nyaring diikuti tindakan lanjut pada tahap pengembangan.

\section{B. PEMBAHASAN}

Implementasi gerakan literasi sekolah yang ada di SDN-6 Madurejo sampai kepada tiga tahap yaitu: tahap pembiasaan yaitu menumbuhkan minat baca melalui 15 menit membaca buku non pelajaran, Tahap pengembangan yaitu siswa menganalisis atau menceritakan kembali buku yang telah mereka baca dengan cara story map atau diskusi buku. Tahap pembelajaran yaitu menanggapi teks buku bacaan pengayaan dan buku pelajaran seperti bahasa indonesia, matematika, agama dsb.

Faktor-faktor pendukung dan penghambat gerakan literasi sekolah yang ada di SDN-6 Madurejo antara lain yaitu: Sarana dan prasarana sekolah yang memadai seperti adanya pojok perpustakaan di tiap-tiap kelas yang sudah disediakan disekolah, speaker pengeras suara, ketersedian buku yang lengkap, adanya program sumbangan buku bagi orang tua pada saat kenaikan kelas dengan sukarela, sumbangan buku dari guru secara pribadi dan sukarela kepada sekolah, program sumbangan buku dari alumni SDN-6 Madurejo melalui media sosial seperti facebook menjadikan beberapa program di atas memperkaya jumlah buku yang ada di perpus sekolah, Adanya tim booklovers yang membantu kegiatan literasi yang ada di sekolah.

Faktor penghambat yaitu: adanya kegiatan diluar jam skegiatan belajar mengajar seperti halnya rapat sekolah, yang menjadikan kegiatan literasi sekolah terganggu dan ditiadakan, kurangnya minat baca siswa, kurangnya motivasi guru agar menjadikan siswa gemar membaca, kondisi kelas yang tidak kondusif saat diadakanya kegiatan literasi.

Solusi gerakan literasi sekolah yang ada di SDN-6 Madurejo yaitu Memotivasi siswa agar terus memiliki semangat dalam mengikuti kegiatan literasi sekolah, Memberikan arahan atau teguran kepada siswa apabila tidak mengikuti kegiatan literasi sekolah dengan baik, Menghimbau kepada seluruh warga sekolah baik guru ataupun siswa untuk gemar membaca dan menullis agar menjadi pribadi yang literat, menjaga kebersihan lingkungan 
sekolah agar kegiatan literasi yang ada disekolah dapat berjalan dengan nyaman.

\section{PENUTUP}

\section{A.Simpulan}

Adapun dalam pelaksanaan kegiatan gerakan literasi SDN-6 Madurejo, sekolah ini memiliki srtuktur penanggung jawab yang diketuai oleh kepala yang bertugas megawasi serta mejadikan motor atau penggerak utama jalanya kegiatan literasi SDN-6 Madurejo. Perpustakaan mini di sekolah menjadi media pendukung utama sebab di dalam perpustakaan terdapat berbagai sumber ilmu serta informasi yang bisa dengan mudah didapat oleh warga sekolah yaitu dengan membaca koleksi buku-buku yang ada. Tentu saja kesadaran dari warga sekolah sendirilah yang menjadi poin penting terlaksananya gerakan literasi yang baik dan menjadikan warga sekolah menjadi pribadi yang literat.

Faktor-faktor pendukung dan penghambat gerakan literasi sekolah yang ada di SDN-6 Madurejo antara lain yaitu: Sarana dan prasarana sekolah yang memadai seperti adanya pojok perpustakaan di tiap-tiap kelas yang sudah disediakan disekolah, speaker pengeras suara, ketersedian buku yang lengkap, adanya program sumbangan buku bagi orang tua pada saat kenaikan kelas dengan sukarela, sumbangan buku dari guru secara pribadi dan sukarela kepada sekolah, program sumbangan buku dari alumni SDN-6 Madurejo melalui media sosial seperti facebook menjadikan beberapa program di atas memperkaya jumlah buku yang ada di perpus sekolah, Adanya tim booklovers yang membantu kegiatan literasi yang ada di sekolah.

Faktor penghambat yaitu: adanya kegiatan diluar jam skegiatan belajar mengajar seperti halnya rapat sekolah, yang menjadikan kegiatan literasi sekolah terganggu dan ditiadakan, kurangnya minat baca siswa, kurangnya motivasi guru agar menjadikan siswa gemar membaca, kondisi kelas yang tidak kondusif saat diadakanya kegiatan literasi.

Solusi gerakan literasi sekolah yang ada di SDN-6 Madurejo yaitu Memotivasi siswa agar terus memiliki semangat dalam mengikuti kegiatan literasi sekolah, Memberikan arahan atau teguran kepada siswa apabila tidak mengikuti kegiatan literasi sekolah dengan baik, Menghimbau kepada seluruh warga sekolah baik guru ataupun siswa untuk gemar membaca dan menulis agar menjadi pribadi yang literat, menjaga kebersihan lingkungan sekolah agar kegiatan literasi yang ada disekolah dapat berjalan dengan nyaman.

\section{B. Saran}

Berdasarkan kesimpulan dari penelitian, maka penulis pada bagian ini mengemukakan saran kepada:

a) Menjalankan peran dan tugasnya dengan baik sebagai kepala sekolah dan melaksanakan program pendidikan sesuai dengan amanah nasional serta melaksanakan program-program pemerintahan seperti kegiatan literasi sekolah dengan lebih baik.

b) Menjaga StakeHolder di lingkungan SDN-6 Madurejo agar tercipta suasana belajar yang kondusif dan perkembangan lembaga pendidikan yang di pimpinnya bisa terus maju dan selaras sesuai dengan cita-cita bangsa.

2. Kepada seluruh guru yang ada di SDN-6 Madurejo, untuk selalu memberotivasi kepada siswa agar dapat menjalankan kegiatan literasi sekolah dengan baik, sehingga siswa dapat menjadi pribadi literat.

3. Kepada seluruh siswa dan siswi SDN6 Madurejo agar memiliki semangat yang tinggi dalam menuntut ilmu, dan mengikuti semua kegiatan yang ada di sekolah dengan baik.

\section{DAFTAR PUSTAKA}

Anderson, L dan Krathwohl, D, 201I, Kerangka Landasan Untuk

Pembelajaran, Pengajaran, Pengajaran dan Asesmen Revisi Taksonomi Pendidikan Bloom. Yogyakarta: Pustaka Pelajar

Arikunto, Suharsani, 2006. Prosedur penelitian suatu pendekatan. Jakarta: Rineka Cipta 
Budiwati Eni, Mulyani, dkk, 20I5. Budaya Baca di Era Digital. Surakarta: Lembaga Ladang Kata

Dendy S, 2008. Kamus Besar Bahasa Indonesia. Jakarta: Gramedia Pustaka Utama Hadi Sutrisno, 1990. Metodologi Research I. Yogykarta: Fakultas Psikologi UGM Moelong. Lexy.J, 20II. Metode Penelitian Kualitatif, Bandung: Remaja Rosda Karya

Kalida Muhsin, 20I5. Gerakan Literasi Mencerdaskan Negeri, Yogyakarta: Aswaja Pressindo

Kamus Besar Bahasa Indonesia (KBBI), 2002, Jakarta: Balai Pustaka Kemendikbud, 20I5. Panduan Gerakan Literasi Sekolah

Hardiningtyastri, 2014. Perpustakaan dan Budaya Literer, Jakarta Utara: Sinotif Publishing

Romdhoni Ali, 2013. Alqur'an dan Literasi, Linus : Literatur Nusantara Sugiyono, 20II.Metode penelitian Kualitatf,Kuantitatif dan R\&D,Bandung: Alfabeta

Usman, Nurdin, 2002. Konteks Implementasi Berbasis Kurikulum, Jakarta: PT.

Raja Grafindo Persada http://dikdas.kemdikbud.go.id/wpcontent/uploads/2016/03/DesainInduk- Gerakan-Literasi-Sekolah I.pdf 21:19 WIB 28, 092017. http://www.matrapendidikan.com/2016/07/opt imasi-program-literasi-di- sekolah.html I5:00 WIB 28, 092017.

http://repositori.perpustakaan.kemdikbud.go.i d/358/I/Manual-PendukungPelaksanaan-Gerakan-LiterasiSekolah.pdf I4:00 WIB, 20, 092017. 